\title{
BENTUK DAN FUNGSI DEIKSIS DALAM TAJUK RENCANA PADA SURAT KABAR SOLOPOS EDISI 2017 DAN RELEVANSINYA SEBAGAI BAHAN AJAR PEMBELAJARAN TEKS EDITORIAL DI SEKOLAH MENEGAH ATAS
}

\author{
Meilda Maharani Purwandari, Ani Rakhmawati, Slamet Mulyono \\ Universitas Sebelas Maret \\ Surel: meildamaharani@gmail.com
}

\begin{abstract}
Abstrak : Tujuan penelitian ini adalah untuk mendeskripsikan dan menjelaskan: (1) bentukbentuk deiksis yang terdapat dalam Tajuk Rencana surat kabar Solopos edisi 2017; (2) fungsi penggunaan deiksis dalam Tajuk Rencana surat kabar Solopos edisi 2017; (3) relevansinya sebagai bahan ajar pembelajaran teks editorial di sekolah menengah atas. Penelitian ini merupakan penelitian deskriptif kualitatif dengan sumber data berasal dari Tajuk Rencana surat kabar Solopos edisi 2017. Teknik sampling penelitian ini menggunakan purposive sampling dan menggunakan analisis isi dan wawancara. Teknik uji validitas data yang digunakan yaitu triangulasi teori. Hasil Penelitian ini adalah 1) Ditemukan 5 bentuk deiksis yakni, deikis persona, deiksis tempat/ ruang, deiksis waktu, deiksis wacana, dan deiksis sosial; 2) Berdasarkan analisis ditemukan fungsi-fungsi penggunaan deiksis pada Tajuk Rencana surat kabar Solopos edisi 2017 adalah a) fungsi deiksis persona, b) Fungsi deiksis tempat/ ruang, c) Fungsi deiksis waktu, d) fungsi deiksis wacana, e) fungsi deiksis sosial; 3) Tajuk Rencana pada surat kabar Solopos edisi 2017 memenuhi kriteria sebagai bahan ajar pembelajaran teks editorial di sekolah menengah atas.
\end{abstract}

Kata Kunci: deiksis, bentuk deiksis, fungsi deiksis, Tajuk Rencana Solopos, bahan ajar, teks editorial

\section{FORMS AND FUNCTIONS OF DEIXIS IN EDITORIAL OF THE SOLOPOS NEWSPAPER 2017 EDITION AND ITS RELEVANCE AS LEARNING MATERIAL OF EDITORIAL TEXT IN SENIOR HIGH SCHOOL}

\begin{abstract}
Abtract: This Analysis explain and describe: (1) the forms of deixis contained in the editorial of Solopos edition 2017; (2) the use of the deixis function in the editorial of Solopos edition 2017; (3) its relevance as teaching material of editorial text in high school. This research is a qualitative descriptive research with source data derived from editorial paper Solopos Edition 2017. Sampling technique of this research using purposive sampling and using document analysis and interview. Technique of data validity test that used is triangulation theory. The results of this research are 1) found 5 deixis form namely, deixis persona, deixis place/ space, deixis time, deixis discourse, and social deixis; 2) Based on the analysis found the functions of the use of deixis at Solopos Editorial Edition 2017 a) the function deiksis persona, b) The deixis function of place, c) The time dextis function, $d$ ) the function of the discourse of discourse, e) the social deixis function; 3) The Editor's editorial in the 2017 edition of Solopos matching with the criteria as teaching material for editorial texts in high school.
\end{abstract}

Keywords: Form, fungtion, deixis, newspaper, editorial, Solopos, teaching materials, editoiral text

\section{PENDAHULUAN}

Deiksis sebagai salah satu kajian pragmatik. Deiksis memiliki referen yang berpindah-pindah tergantung pada situasi penggunaanya. Deiksis membuat makna bahasa menjadi lebih teratur dan efektif sehingga tidak menyebabkan kerancuan dan tidak menimbulkan presepsi berbeda pada penerima bahasa. Penggunaaan 
bahasa memberikan kemudahan dalam berinteraksi dan berkomunikasi secara lisan dan tulisan. Penggunaan bahasa dapat bersifat efektif dan teratur jika diketahui konteks penggunaannya. Deiksis sangat dibutuhkan dalam penggunaan bahasa karena deiksis mengidentifikasi sebuah makna yang terkandung dalam bahasa dan hanya diketahui apabila sudah berada dalam konteks peristiwa atau situasi bahasa. Deiksis menyangkut cara-cara bahasa mengekspresikan ciri-ciri konteks ujaran dalam pemakaian bahasa (Dylgeri dan Ledia, 2013:88).

Pemakaian bahasa dalam komunikasi memberikan kemudahan bagi pemakinya. Salah satu kemudahan tersebut adalah adanya sistem pengacuan dan referensial. Sistem pengacuan dapat memberikan kemudahan namun juga menimbulkan ketidakjelasan, kebingungan, dan kesalahpahaman makna antarpengguna bahasa mengenai pemahaman makna dan referen atau acuan. Seseorang mampu memahami referen dari sebuat tuturan harus bisa mengidentifikasi konteks dan pertuturan. Pemahaman terhadap referen berhubungan erat dengan pemahaman terhadap deiksis. Hal ini sejalan dengan Purwo (1985:1) yang mengemukakan bahwa sebuah kata bersifat deiktis apabila referennya berpindah-pindah atau bergantiganti, tergantung pada orang yang menjadi pembicara dan tergantung pada saat dan tempat dituturkannya kata-kata itu. Deiksis terbagi menjadi lima bentuk, yaitu deiksis persona, deiksis tenpat/ruang, deiksis waktu, deiksis wacana, dan deksis sosial. Kelimat deiksis tersebut saling mempengaruhi dan melengkapi satu sama lain. Deiksis berguna sebagai penjelas makna tuturan sehingga makna yang terkandung dalam tuturan dapat diterima dengan baik oleh pembaca. Hal ini merupakan tujuan dalam berbahasa yang perlu ditingkatkan pada setiap pengguna bahasa. Penggunaan deiksis dapat ditemukan di berbagai sumber. Salah satu sumber yang mengandung kata dan frasa deiksis adalah surat kabar. Surat kabar menjadi alat komunikasi untuk menyampaikan pesan kepada pembaca yang berisi berbagai macam penyajian informasi berita yang terbit secara berkelanjutan atau bisa disebut harian. Surat kabar tidak akan terlepas dari konteks berita dan isinya. Setiap hari masyarakat dapat memperoleh informasi terbaru dalam berbagai bidang melalui surat kabar.

Surat kabar yang terkenal di daerah Solo salah satunya adalah Solopos. Solopos mampu menyajikan informasi yang aktual di sekitar maupun nasional. Solopos merupakan sebuah surat kabar harian yang di dalamnya memuat informasi tulisan dari berbagai aspek. Solopos berusaha menyajikan berita yang mengungkapkan fakta dan kepentingan masyarakat mulai dari berita sosial, budaya, ekonomi, dan politik. Terdapat berbagai macam wacana yang ada di surat kabar Solopos. Salah satu wacana yang selalu ada dalam surat kabar adalah Tajuk Rencana. Tajuk Rencana berisi pandangan atau pendapat redaksi tentang persoalan atau peristiwa yang aktual dan menjadi pusat perhatian (Yeri, 2015:18). Tajuk Rencana biasanya mengungkapkan adanya informasi atau masalah aktual, penengasan pentingnya masalah, opini redaksi tentang masalah, kritik dan saran atas permasalahan, dan harapan redaksi akan peran serta pembaca. Peneliti memilih Tajuk Rencana yang terdapat pada surat kabar Solopos karena disajikan secara aktual sehingga mengandung unsur deiksis yang berbeda setiap harinya.

Setiap Tajuk Rencana yang dibuat harus mengacu pada konteks dan tuturannya sehingga maknannya dapat tersampaikan pada pembaca. Deiksis yang ditemukan pada Tajuk Rencana, belum tentu itu dapat bermakna atau bersifat deiksis. Deiksis pada Tajuk Rencana perlu diteliti agar tidak terjadi kesalahan pemahaman terhadap makna dalam tuturan Tajuk Rencana. Jika seseorang ingin memahami makna mengenai tuturan yang ada di Tajuk Rencana, pembaca harus 
memahami konteks dan referennya. Hal ini secara tidak langsung juga meningkatkan pemahaman mengenai kata atau frasa yang mengandung makna deiksis. Hal inilah yang juga menjadi salah satu alasan lain peneliti dalam meneliti deiksis pada Tajuk Rencana.

\section{METODE PENELITIAN}

Penelitian ini bersifat kualitatif dan menggunakan analisis isi. Sumber data yang digunakan dalam penelitian ini adalah dokumen yang berupa Tajuk Rencana pada surat kabar Solopos edisi 2017. Data yang digunakan dalam penelitian ini adalah kalimat-kalimat yang mengandung deiksis yang terdapat dalam Tajuk Rencana pada surat kabar Solopos edisi 2017.

Teknik pengambilan sampel yang digunakan adalah teknik sampel bertujuan (purposive sampling). Teknik pengumpulan data yang digunakan dalam penelitian ini adalah teknik dokumentasi. Validitas data yang digunakan dalam penelitian ini adal triangulasi teori. Analisis data pada penelitian ini dilakukan dengan menggunakan metode padan. Metode padan atau disebut metode identitas ialah metode yang dipakai untuk mengkaji atau menentukan identitas satuan lingual tertentu dengan memakai alat penentu yang berada di luar bahasa, terlepas dari bahasa, dan tidak menjadi bagian dari bahasa yang bersangkutan Peneliti menggunakan metode padan karena dalam penelitian ini sudah memeiliki hubungan dengan hal-hal di luar bahasa yang bersangkutan bagaimanapun sifat hubungan itu.

\section{HASIL DAN PEMBAHASAN.}

Deiksis-deiksis yang ditemukan dala Tajuk Rencana pada surat kabar Solopos edisi 2017 terdiri dari lima bentuk deiksis yang dijabarkan menjadi: deiksis persona, deiksis tempat/ruang, deiksis waktu, deiksis wacana, dan deiksis sosial, masingmasing deiksis tersebut memiliki fungsi yang berbeda-beda sesuai dengan penggunaan deiksis tersebut.

Deiksis yang eprtama dalah deiksis persona. Berdasarkan hasil penelitian ini, dapat ditemukan lima bentuk deiksis persona yakni, persona pertama jamak, persona ketiga tuggal, dan persona ketiga jamak. Menurut Purwo (1984: 24) bentuk kata ganti persona jamak terdiri dari kata kita dan kami. Deiksis kedua, deiksis persona ketiga tunggal. Menurut Sunarwan dkk (2014:4) bentuk persona ketiga tunggal terdiri dari kata dia, ia, beliau, kata ganti orang ketiga (-nya). Deiksis ketiga, deiksis persona ketiga jamak yang ditandai dengan kata mereka dan kalian.

Deiksis kedua adalah deiksis tempat atau ruang. Deiksis tempat atau ruang berhubungan dengan pemahaman lokasi atau tempat yang digunakan peserta pertuturan dalam situasi penutur (Nadar, 2009: 55-56). deiksis ruang dapat dibedakan menjadi tiga jenis yakni deiksis ruang yang berupa pertama, leksem lokatif meliputi kata sini, situ, dan sana. Kedua, leksem demonstratif meliputi kata ini, itu, begini, dan begitu. Ketiga, leksem temporal meliputi kata kini, dan dini.

Deiksis ketiga adalah deiksis waktu. Deiksis waktu adalah pengungkapan waktu ketika suatu tuturan atau ujarana berlangsung. Deiksis waktu dapat diungkapkan dengan leksem waktu, leksem ruang, dan penambahan kata ini atau itu yang dirangkaikan pada leksem waktu (Sunarwan, 2014: 5). Deiksis waktu berkaitan dengan waktu relatif penutur atau penulis dan mitra tutur atau pembaca. Bahasa Indonesia mengungkapkan waktu dengan sekarang untuk waktu kini, tadi, dan dulu untuk waktu lampau, nanti untuk waktu yang akan datang. Hari ini, kemarin, dan besok juga merupakan hal yang relatif, dilihat dari kapan satu ujaran diungkapkan. Elfrida (2015: 174) menyebutkan bahwa deiksis waktu adalah kata yang mengacu pada kapan kata itu diucapkan. Deiksis waktu diungkapkan dengan kata keterangan waktu dan leksem ruang yang menyatakan waktu. Leksem 
pagi, siang, sore, dan malam tidak deiksis jika leksem tersebut ditentukan berdasarkan posisi planet bumi terhadap matahari. Leksem pagi, siang, sore, dan malam menjadi deiksis jika patokannya bukan posisi bumi terhadap matahari. Deiksis waktu diungkapkan dengan kata sekarang, kemarin, besok, dulu, tadi, nanti, dan kelak. Leksem ruang yang dapat digunakan untuk mengungkapkan waktu adalah leksem ruang seperti depan, belakang, panjang, pendek, datang, lalu, tiba, mendekat, panjang, dan pendek.

Deiksis kempat adalah deiksis wacana. Deiksis wacana dapat dibagi menjadi dua yaitu deiksis anafora dan katafora. Purwo (1984: 104) mengungkapkan bahwa anafora adalah penunjukan yang mengacu pada konstituen di sebelah kirinya. Artinya deiksis anafora penunjukan kembali kepada sesuatu yang telah disebutkan sebelumnya dalam suatu ujaran. Bentuk deiksis wacana anafora digunakan kata dia, ia bentuk terikat nya, mereka , yang bersangkutan, itu, yang pertama, yang kedua, satunnya, yang tersebut belakang, yang belakang itu, (yang) terakhir ini, tersebut, tadi, demikian, sebagai berikut, seperti di bawah ini, berikut ini, dan sebagainya. Deiksis wacana katafora adalah penunjukan yang mengacu pada konstituen di sebelah kanannya. Artinya penunjukan sesuatu yang akan disebut dalam tuturan atau ujaran. Bentuk deiksis wacana Bentuk deiksis wacana katafora ditandai dengan kata ini, begini, yakni, yaitu, demikian, sebagai berikut, seperti di bawah ini, berikut ini, dan sebagainya.

Deiksis yang kelima adalah deiksis sosial, Menurut Putrayasa (2014:53) mengatakan deiksis sosial menunjukan perbedaan-perbedaan sosial (perbedaan yang disebabkan oleh faktor-faktor sosial seperti jenis kelamin, usia, kedudukan di dalam masyarakat, pendidikan, pekerjaan, dan sebagainya) yang ada pertisipan dalam sebuah komunkasi verbal yang nyata, terutama yang berhubungan dengan segi peran antara penutur dan petutur, atau penutur dengan topik atau acuan lainnya. Bentuk deiksis sosial adalah kata sapaan seperti ibu, bapak, saudara, nyonya, dan sebagainya. Kata ganti orang seperti engkau, kamu dan penggunaan gelar. Bentuk tersebut merupakan bentuk honorifics atau sopan-santun berbahasa. Bentuk lain yang termasuk ke dalam deiksis sosial adalah bentuk deiksis sosial eufemisme atau penggunaan kata halus.

Deiksis yang ditemukan dalam Tajuk Rencana pada surat kabar Solopos memiliki fungsi yang berbeda-beda seusai dengan jenis deiksisnya. Secara umum, deiksis berfungsi untuk membantu pembaca dalam memahami dan mengerti isi dari suatu bacaan atau wacana. Secara khusus deiksis juga mempunyai fungsi yang berbeda sesuai dengan jenis dan konteks yang ada dalam deiksis tersebut.

Deiksis persona mempunyai tiga fungsi. Pertama Merujuk pada orang yang dibicarakan Fungsi deiksis merujuk pada orang yang dibicarakan menggunakan kata ganti persona ketiga tunggal. Karena fungsi kata ganti persona ketiga tunggal adalah merujuk pada orang yang dibicarakan. Bentuk yang digunakan ditandai dengan kata ia, dia, bentuk terikat (-nya). Kedua merujuk pada bentuk inklusif Fungsi deiksis merujuk pada bentuk inklusif ditandai dengan penggunaan kata kita Menurut Purwo (1984: 24) kita adalah gabungan antara persona pertama dan kedua. Fungsi ketiga, Merujuk pada bentuk jamak Fungsi deiksis persona yang ketiga yaitu merujuk pada bentuk jamak. Fungsi ini ditunjukan dengan penggunaan kata ganti persona ketiga jamak. Bentuk yang ditemukan dalam fungsi ketiga ini di tandai dengan penggunaan kata mereka.

Deiksis tempat/ waktu mempunyai beberapa fungsi berdasarkan analisis deiksis dalam Tajuk Rencana pada surat kabar Solopos edisi 2017 dapat ditemukan fungsi deiksis tempat/ ruang. Terdapat dua fungsi deiksis tempat/ ruang yang ditemukan. Fungsi pertama merujuk pada tempat yang dekat dengan pembicara yang 
ditandai dengan kata sini dan ini. Fungsi kedua merujuk pada tempat yang agak jauh dari pembicara. Ditandai dengan kata situ dan itu. Hal ini sebagaimana diungkapkan Sumarlam (dalam Sunarwan dkk, 2014:8) membedakan deiksis tempat antara yang dekat dengan penutur (sini, ini) yang agak dekat dengan penutur (situ,itu), yang jauh dengan penutur (sana), dan yang merujuk secara eksplisit. Dalam penelitian ini hanya menemukan dua fungsi. Fungsi merujuk tempat yang dekat dengan pembicara dan fungsi merujuk tempat yang agak dekat dengan pembicara.

Fungsi deiksis waktu berdasarkan analisis deiksis pada Tajuk Rencana surat kabar Solopos edisi 2017 dapat ditemukan empat fungsi deiksis waktu. Fungsi pertama merujuk pada saat tuturan. Fungsi merujuk pada saat tuturan ditandai dengan penggunaan kata kini dan sekarang. Selain itu, penambahan kata ini pada leksem waktu juga menunjukan fungsi pada saat tuturan dilakukan. Fungsi kedua merujuk pada waktu lampau atau sebelum saat tuturan. Fungsi merujuk pada waktu lampau atau sebelum saat tuturan berlangsung ditunjukan dengan penggunaan leksem waktu yang menyatakan waktu lampau. Selain dengan penggunaan leksem waktu, fungsi ini juga ditunjukan dengan pemakian leksem ruang lalu dengan penambahan kata itu pada leksem waktu. Fungsi ketiga merujuk pada waktu sesudah saat tuturan. Fungsi merujuk pada waktu sesudah tuturan ditunjukan dengan penggunaan leksem waktu yang menyatakan waktu yang akan datang, seperti tahun berikutnya, tahun depan, besok, dan lain sebagainya. Fungsi keempat menggambarkan kejadian yang faktual atau pungtual. Fungsi deiksis waktu untuk menggambarkan kejadian yang faktual atau pungtual ditunjukan dengan penggunaan kata-kata yang mengungkapkan fakta.

Fungsi deiksis wacana berdasarkan hasil analsis deiksis dalam Tajuk Recana pada surat kabar Solopos edisi 2017 dapat ditemukan fungsi deiksis wacana. Terdapat tiga fungsi deiksis wacana yang ditemukan. Fungsi pertama merujuk pada hal yang telah disebutkan (anafora). Katakata yang tergolong menjadi pemarkhan anaforis di antaranya ini, itu, -nya, yang pertama, yang kedua, yang satunya, yang bersangkutan, tersebutdan lain sebagainya. Fungsi kedua merujuk pada yang akan disebutkan (katafora). Kata yang dapat digunakan sebagai pemarkhan kataforis di antaranya adalah ini, begini, yakni, yaitu, demikian, adalah dan sebagainya. Fungsi terakhir atau ketiga menyimpulkan sesuatu. Fungsi menyimplkan sesuatu ditunjukan dengan penggunaan kata demikian.

Fungsi deiksis sosial Secara umum, deiksis sosial berfungsi sebagai bentuk kesopanan dalam berbahasa. Secara khusus, fungsi deiksis sosial ditentukan oleh konteks yang terdapat dalam suatu tuturan. Fungsi khusus deiksis sosial yang dapat ditemukan pada analisis Tajuk Rencana pada surat kabar Solopos edisi 2017 ada dua. Fungsi pertama sebagai pembeda tingklat sosial penutur dan mitra tutur. Fungsi kedua, untuk menjaga sopan santun berbahasa. Fungsi ketiga untuk merujuk bentuk sosial kemasyarkatan Fungsi bentuk sikap sosial kemasyarakatan ditunjukan dengan penggunaan kata-kata tertentu yang berhubungan dengan keadaan di masyarakat.

Tujuan kegiatan pembelajaran teks editoiral di sekolah menegah atas adalah untuk memberi pemhaman pada siswa tentang teks editorial berkaitan dengan struktur, kaidah kebahasaan dan penulisan teks editorial.berdasarkan tujuan pembelajaran teks editorial maka diperlukan bahan ajar untuk mendukung pembelajaran teks editorial salah satunya Tajuk Rencana yang terdapat pada surat kabar untuk dijadikan sebagai bahan ajar dalam pembelajaran teks editorial di SMA karena sesuai dengan kurikulum yang ada. Sependapat dengan hal tersebut, Panen (dalam Prastowo 2014:42) menyebutkan bahwa bahan ajar bahan atau materi pembelajaran yang disusun secara 
sistematis yang digunakan guru dan peserta didik dalam proses pembelajaran. Maksudnya bahan ajar harus disesuaikan dengan kurikulum dan pengembangannya, yaitu silabus dan rencana pelaksanaan pembelajaran. Hal itu diperlukan karena bahan ajar akan digunakan pendidikan untuk membantu tugas mereka dalam proses belajar mengajar untuk mencapai tujuan pembelajaran.

Berbagai macam bahan ajar yang dapat digunakan dalam pembelajaran. Bahan ajar yang dapat digunakan dapat berbentuk buku sumber utama ataupun penunjang lainnya. Bahan bacaan penunjang, seperti: jurnal, hasil penelitian, majalah, koran, brosur serta alat pembelajaran yang terkait dengan indikator dan kompetensi dasar yang ditetapkan. Pada pembelajaran bahasa Indonesia khususnya pembelajaran teks editorial, guru perlu mempersipkan bahan ajar yang baik untuk digunakan. Menurut Prastowo (2014: 58-60) ada tiga prinsip untuk memilih kriteria bahan ajar. Pertama, prinsip relevansi. Maksudnya, bahan ajar yang dipilih hendaknya ada relasi dengan pencapaian standar kompetensi maupun kompetensi dasar. Kedua, prinsip konsistensi, maksudnya bahan ajar yang dipilih memiliki keajegan. Jadi, antara kompetensi dasar yang mesti dikuasai peserta didik dengan bahan ajar yang disediakan memiliki keselarasan dan kesamaan. Ketiga, prinsip kecukupan, maksudnya, ketika memilih bahan ajar hendaknya dicari yang memadai untuk membantu siswa menguasai kompetensi dasar yang diajarkan.

Berdasarkan paparan di atas, maka kriteria pemilihan bahan ajar dapat ditarik garis besar bahwa kriteria bahan ajar yang baik dan sesuai dengan pembelajaran teks editorial yaitu pertama, bahan ajar Tajuk Rencana yang terdapat pada surat kabar Solopos edisi 2017 sesuai isi materi pembelajaran teks editorial. Kedua, bahan ajar Tajuk Rencana yang terdapat pada surat kabar Solopos edisi 2017 dapat mendukung dalam mencapai tujuan pembelajaran teks editorial. Ketiga, bahan ajar mudah didapatkan. Keempat, bahan ajar Tajuk Rencana yang terdapat pada surat kabar Solopos edisi 2017 sesuai dengan kompetensi dasar dan kurikulum.

\section{SIMPULAN}

Berdasarkan analisis data mengenai bentuk dan fungsi deiksis dalam Tajuk Rencana pada surat kabar Solopos edsii 2017 dapat disimpulkan bahwa ditemukan 5 macam bentuk deiksis yakni, deiksis persona, deiksis tempat/ ruang, deiksis waktu, deiksis wacana, dan deiksis sosial. Bentuk-bentuk deiksis yang ditemukan yaitu persona pertama jamak, persona ketiga tunggal, dan persona ketiga jamak. Bentuk-bentuk deiksis tempat/ ruang yang ditemukan deiksis tempat/ ruang lokatif dan deiksis tempat/ ruang demostratf. Bentuk deiksis waktu yang ditemukan adalah deiksis waktu yang mengguanakan loksem waktu, deiksis waktu yang menggunakan leksem ruang/pengukur ruang, dan deiksis waktu yang menggunakan penambahan kata ini dan itu pada leksem waktu. Bentuk deiksis wacana yang ditemuukan dibedakan menjadi deiksis wacana anfora dan deiksis wacana katafora. Adapun bentuk deiksis sosial yang ditemukan adalah bentuk honoricifcs dan eufimisme.

Setiap deiksis mempunyai fungsi yang berbeda tergantung pada penggunaannya. Berdasarkan hasil analisis di atad dapat diketahui fungsi penggunaan deiksis dalam Tajuk Recana pada surat kabar Solopos edisi 2017 yaitu fungsi deiksis persona, fungsi deiksis tempat/ ruang, fungsi deiksis waktu, fungsi deiksis wacana dan fungsi deiksis sosial. Fungsi deiksis persona yaitu merujuk pada ornag yang dibicarkan, merujuk pada bentuk inklusif dan merujuk pada bentuk jamak. Fungsi deiksis tempat/ ruang yaitu merujul tempat yang dekan dengan pembicara dan merujuk pada tempat yang agak dekat dengan pembicara. Fungsi deiksis waktu yaitu merujuk pada saat tuturan, merujuk pada waktu lampau, atau sebelum saat 
tuturan, dan merujuk pada waktu sesudah tuturan. Fungsi deiksis wacana yairu merujuk pada hal yang telah dibicarkan, merujuk pada hal yang akan dibicarakan, dan menyimpulkan sesuatu. Adapun fungsi deiksis sosial yang ditemukan yaitu pembeda tingkat sosial penutur dan mitra tutur dan menjaga sopan santun bahasa.

Tajuk Rencana Solopos edisi 2017 dapat dijadikan bahan ajar dalam pembelajaran teks editorial di sekolah menengah atas karena memenuhi kriteria bahan ajar yang baik. Kriteria bahan ajar yang sesuai dengan pembelajaran teks editorial yaitu bahan ajar sesuai dengan isi materi pembelajaran pembelajaraan teks editorial. Bahan ajar dapat mendukung pembelajaran untuk mencapai tujuan pembelajaran teks editorial. Bahan ajar mudah didapatkan. Kriteria terakhir bahan ajar harus sesuai dengan kompetensi dasar dan kurikulum pembelajaran teks editorial.

\section{RERERENSI}

Dylgeri, A \& Kazazi, L . (2013). Deixis in Modern Linguistic and Outside. Academic Jurnal of Interdisiciplinary Studies. 2 (4).8796. ISSN 2281-3993.

Purwo, K.B. (1984). Pragmatik dan Pengajaran Bahasa.Yogyakarta: Kanisius

Putrayasa, I.B. (2014). Pragmatik. Graha Ilmu: Yogyakarta

Elfrida, R. P., Manik, S \& Pasaribu, T. (2015). Deixis Used

on Business Brochures Text: A Pragmatics Study. Internasional Jurnal of English Linguistic. 5 (5). 171-182. ISSN 1023-869X

Nadar, FX. (2009). Pragmatik dan Penelitian Pragmati. Yogyakarta: Graha Ilmu

Prastowo, A. (2014). Pengembangan Bahan Ajar Tematik Tinjauan Teoritis dan Praktik. Jakarta: Prenadamedia Grup.

Sunarwan, Ei., Rohmadi, M \& Anindyarini, A. (2014). Analisis Deiksis dalam Cerpen Siswa Kelas $X$ SMA Negeri 1 Karanganya. BASASTRA: Jurnal Penelitian Bahasa Sastra Indonesia dan Pengajarannya. 2(3). 1-11. ISSN 12302-6405

Yeri, Musfita, A \& Handayani, S. (2014). Manajemen Majalah Sekolah (MMS). Surakarta: Bukutujju. 